\title{
Podosphaera clandestina causes powdery mildew on sour cherry in Iran
}

\author{
Mahdi Arzanlou $^{1} \cdot$ Mohsen Torbati $^{1} \cdot$ Abolfazl Narmani $^{1}$
}

Received: 13 October 2016 / Accepted: 19 January 2017 / Published online: 27 January 2017

(C) Australasian Plant Pathology Society Inc. 2017

\begin{abstract}
During 2014-2016, symptoms and signs of a powdery mildew disease were observed on the leaves and twigs of sour cherry (Prunus cerasus) in orchards from Firouragh in the Khoy region (West Azarbaijan province) of Iran. Young leaves and twigs were covered with a powdery growth consisting of mycelium and the asexual reproductive structures of a powdery mildew species. Affected leaves were curled upward and smaller than uninfected leaves, while affected twigs were stunted and often defoliated. The fungus was identified as belonging in the genus Podosphaera, based on morphological characteristics of its asexual state. Chasmothecia were not observed. The PCR amplification and sequencing of its ITS-rDNA revealed that the causal agent was Podosphaera clandestina. This is the first record on the occurrence of $P$. clandestina on sour cherry in Iran.
\end{abstract}

Keywords Chasmothecia $\cdot$ Fibrosin bodies $\cdot$ ITS-rDNA .

Prunus cerasus

Sour cherry (Prunus cerasus) belongs in the subgenus Cerasus in the family Rosaceae. The presumed center of origin for this species is Eastern Europe and southwest Asia, where it originated as a natural hybrid between Prunus avium and Prunus fruticosa (Horvath et al. 2008). Sour cherry is a popular fruit tree in many countries including Iran. According to the statistics of Food and Agriculture Organization (FAO) of the United Nations, in 2013 Iran ranked the fifth in sour cherry production in world with an annual production of

Mahdi Arzanlou

Arzanlou@hotmail.com; Arzanlou@tabrizu.ac.ir

1 Plant Protection Department, Faculty of Agriculture, University of Tabriz, P.O. Box 5166614766, Tabriz, Iran
$106,972 \mathrm{t}$ (FAOSTAT 2013). Although sour cherry is undemanding and very robust, a number of fungal plant pathogens including Monilinia laxa and Stigmina carpophila cause economic crop loss on this host in Iran (Ahmadpour et al. 2009; Leghvani et al. 2016). During 2014-2016, symptoms and signs of a powdery mildew disease were observed on sour cherry trees in orchards of Firouragh in the Khoy region (West Azarbaijan province), Iran. Infected leaves and twigs were collected in paper bags and transported to the mycology laboratory at the Plant Pathology Department, University of Tabriz, Iran. Five specimens were inspected under a stereomicroscope and fungal structures were mounted in distilled water on a glass slide, covered with a coverslip then examined. Microscopic observations were made using an OlympusBX41 light microscope. Thirty measurements were taken of the relevant parameters of the conidiophores and conidia and 95\% confidence intervals were derived for the measurements with the extremes given in parentheses. An Olympus digital camera system (DP 25) and software to analyze photographs was used to capture high-resolution photographs of microscopic fungal structures. A herbarium specimen was deposited in the Fungal Herbarium of the Iranian Research Institute of Plant Protection (IRAN 16861F).

The white powdery coating consisted of mycelium, conidiophores and conidia. The infected terminal leaves were smaller than uninfected terminal leaves with the leaf margins curled upward; infected leaves occasionally became necrotic and defoliated (Fig. 1a-b). The sunken irregular lesions (4-) $5 \times 6(-7) \mathrm{mm}$ in diam, were covered with the white powdery mass and later became necrotic (Fig. 1c-e). On mature leaves, white powdery colonies were covered the entire leaf surface and no malformation was observed (Fig. 1f-g). The preliminary identification of the fungus was performed by an examination of the morphological characters and comparisons with published descriptions (Braun and Cook 2012). The hyphae 

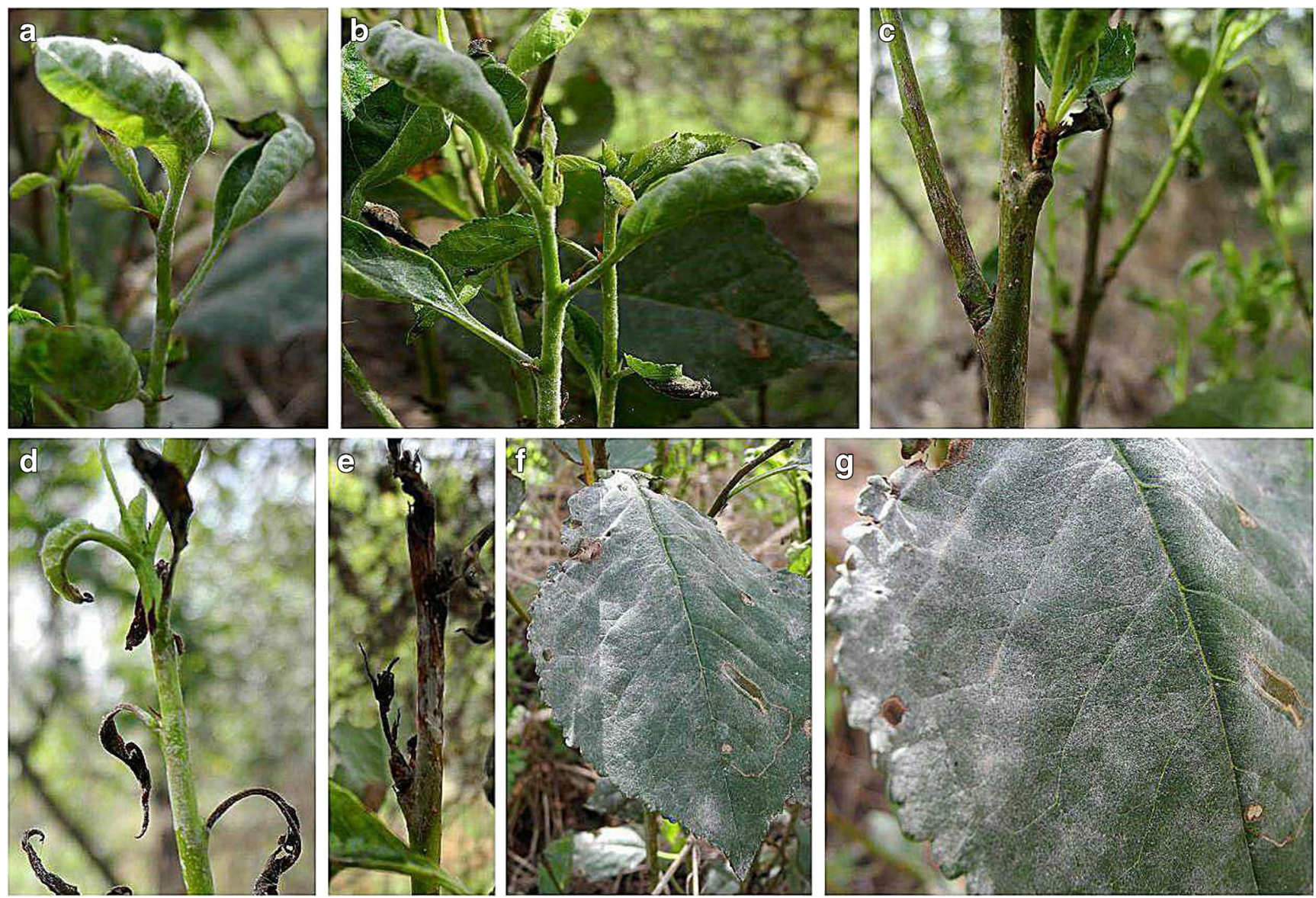

Fig. 1 Symptoms of powdery mildew caused by Podosphaera clandestina on leaves and twigs of sour cherry. a-b heavily infected trees with curled and crinkled leaves. c-e disease symptoms on twigs including stunted growth, leaf necrosis and lesions. f-g disease symptoms on mature leaves

were amphigenous, septate, hyaline, thin-walled, smooth and branched, in patches or effuse. Conidiophores were erect, straight, arising from superficial hyphae on the both surface of leaves, foot cells cylindrical, sometimes slightly narrowed at the very base, (35-) 59-77 (-105) × (5-) 7-8 (-11) $\mu \mathrm{m}$, followed by 1 to 5 shorter cells (Fig. $2 \mathrm{a}, \mathrm{b})$. Conidia were ellipsoid to ovoid with fibrosin bodies and were (14-) 19-35 $(-38) \times(8-)$ 10-20 (-25) $\mu \mathrm{m}$ (Fig. 2c-e). Chasmothecia were absent. Based on the morphological characteristics of asexual morph and host plant association the fungus was identified as member of the genus Podosphaera (Braun and Cook 2012).

The identity of the causal agent was determined based on the sequence data of ITS-rDNA region. Total genomic DNA was exacted from mixture of collection using the following method: a small piece of fungal powdery mass was picked up from the surface of leaf using a sterile toothpick and suspended in $50 \mu \mathrm{l}$ TE buffer in PCR tubes. The fungal mass was mashed with a sterile pipette tip and samples were kept in thermocycler at $95^{\circ} \mathrm{C}$ for $5 \mathrm{~min}$. DNA extracts were stored at $-20{ }^{\circ} \mathrm{C}$ for future use. The primer set ITS1 and ITS4 (White et al. 1990) was used to amplify parts of the rDNA internal transcribed spacer region (ITS1-5.8S-ITS2) using polymerase chain reaction, following the methodology described by
Arzanlou et al. (2013) and Arzanlou and Dokhanchi (2012). The PCR product was sequenced using the same primer set. The obtained sequence was edited using SeqMan software in the Lasergene package (DNASTAR Inc., Madison, WI, USA) and compared with the sequences in GenBank database using BLASTN freeware from www.ncbi.nlm.nih.gov/BLAST. Blast search analysis revealed the identity of species as Podosphaera clandestina. The sequence obtained in study showed $100 \%$ similarity with the representative sequences for Podosphaera clandestina in GenBank (AB026137.1 and DQ139434.1) and clearly deviated from the sequences for the two other Podosphaera species which also occur on sour cherry, namely P. pannosa and P. tridactyla (Vajnaa and Rozsnyay 2006; Braun and Cook 2012). The sequence is now available in GenBank under the accession KY124542.

Although Podosphaera clandestina mainly affects cherry and is a serious problem on this host in nurseries (Horst 2008), it also occurs on a wide range on hosts including Prunus domestica, P. persica, P. armeniaca, Malus pumila, Cydonia oblonga, Crataegus rhipidophylla, Amelanchier spp. and Spiraea spp. (Horst 2008). The complete list of host plant species for $P$. clandestina has been provided by Braun and Cook (2012). Podosphaera clandestina has been previously 

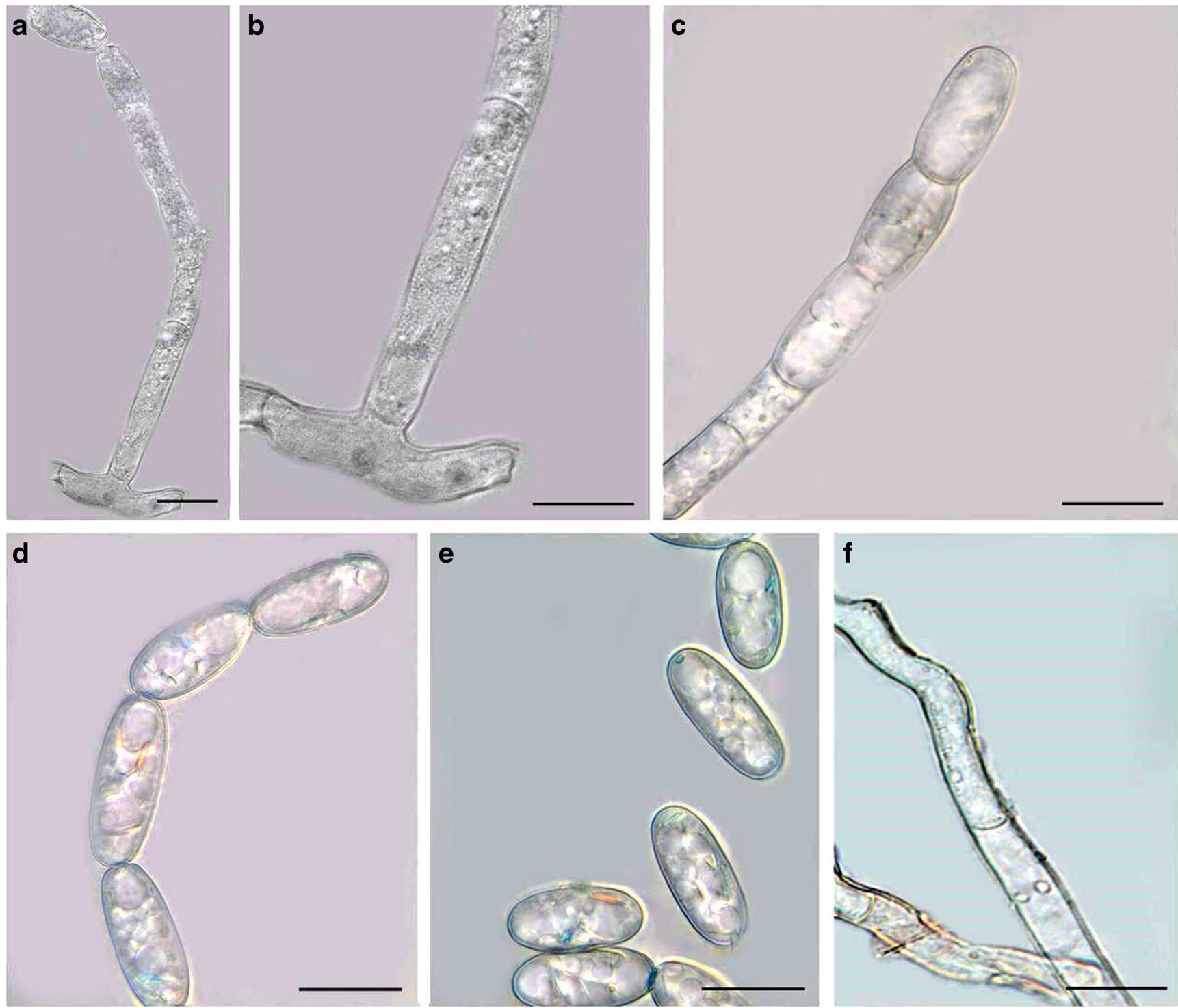

Fig. 2 Podosphaera clandestina. a-b foot cell and conidiophore. c-e macroconidia with fibrosin bodies. f hyphae. Scale: a $20 \mu \mathrm{m}$, b-f $10 \mu \mathrm{m}$

reported on Crataegus spp. and Cydonia oblonga in Iran (Ershad 2009; Khodaparast and Abbasi 2009). Although two other powdery mildew pathogens, Erysiphe prunastri and Phyllactinia guttata, have been reported on sour cherry from Iran (Khodaparast and Abbasi 2009), ours is the first report of P. clandestina on this host in Iran.

Acknowledgements This work was financially supported by the Research Deputy of the University of Tabriz, Iran.

\section{References}

Ahmadpour A, Ghosta Y, Javan-Nikkhah M, Fatahi R, Ghazanfari K (2009) Isolation and pathogenicity tests of Iranian cultures of the shot hole pathogen of Prunus species, Wilsonomyces carpophilus. Australas Plant Dis Notes 4:133-134
Arzanlou M, Dokhanchi H (2012) Calosphaeria canker of almond caused by Calosphaeria pulchella in Iran. Arch Phytopathol Plant Protect 46(2):215-226

Arzanlou M, Moshari S, Salari M, Badali H (2013) Molecular characterization and pathogenicity Phaeoacremonium spp. associated with esca disease of grapevine in northern Iran. Arch Phytopathol Plant Protect 46(4):375-388

Braun U, Cook RTA (2012) Taxonomic manual of the Erysiphales (powdery mildew). CBS Biodiversity Series 11:1-707

Ershad D (2009) Fungi of Iran, 3rd edn. Iranian Research Institution of Plant Protection, Tehran

FAOSTAT (2013) Available at http://faostat3.fao.org/download/Q/QC/E Horst RK (2008). Westcott's Plant Disease Handbook (7th Edn.), Springer-Verlag, Dordrecht

Horvath A, Zanetto A, Christmann H, Laigret F, Tavaud M (2008) Origin of sour cherry (Prunus cerasus L.) genomes. Acta Hort 795:131136

Khodaparast SA, Abbasi M (2009) Species, host range and geographical distribution of powdery mildew fungi (Ascomycota: Erysiphales) in Iran. Mycotaxon 108:213-216 
Leghvani M, Arzanlou M, Babai-ahari A (2016). Identification of Monilinia species associated with brown rot disease of stone fruit trees in West Azarbaijan province of Iran, based on morphological and molecular characteristics. Appl Res Plant Protect 5:143-157.(in Farsi; English abstract)
Vajnaa L, Rozsnyay Z (2006) First report of powdery mildew caused by Podosphaera pannosa on a new host - sour cherry - in Hungary. Plant Pathol 55:576

White TJ, Bruns TD, Lee SB, Taylor JW (1990) Amplification and sequencing of fungal ribosomal RNA genes for phylogenetics. In: Innis N, Gelfand D, Sninsky J, White TC (eds) PCR protocols and applications - a laboratory manual. Academic, New York 